\title{
A Study of Gender Inequality in India
}

\author{
Priti Jha ${ }^{1}$, Niti Nagar ${ }^{2}$
}

\section{ABSTRACT:}

This study considers the gender inequality that exists among every region, social class and prevents the growth of Indian economy from improving the lives of Indian people. The reality of gender inequality in India is very complex and diversified, because it exists in every field like education, employment opportunities, income, health, cultural issues, social issues, economic issues etc. An attempt has been made to find out those factors which are responsible for this problem in India. So, this paper highlights the multi-dimensional context of gender inequalities prevalent in India. Overall, the study indicates the inequality in economic, social, cultural and legal biasness which are of a great challenge for policy-makers and social scientists to establish proper equality in the entire social field. The researchers have tried to suggest some relevant strategies and policies implication for reducing this gender inequality and to promote the dignified position for Indian women.

Keywords: Gender Inequality, Economic, Social \& Cultural issues

After the World War II, in the post modernization era, one of the issues which had attracted the attention of the policy makers and social scientists was gender issues and concerns. Gender issues mean the discussion on both men and women, though women who suffer from gender inequality. From all gender issues, gender inequality is the most prevalent in India. Consideration of gender inequality is now common in Government, Non-Government organizations, and in the politics in India. The policy makers are strongly believed that a positive commitment to gender equality and equity will strengthen every area of action to reduce poverty because women can bring new energy and new sights. A lot of debates are going on women and their development since last few decades. Thus, several national and international organizations are trying to promote the advancement of women \& their full participation in developmental process \& trying to eliminate all forms of inequality against women. The importance of feminism has been steadily growing and gaining intellectual legitimacy.

\section{GENDER INEQUALITY:-}

Gender Inequality means disparity between men and women in different social, economical \& political, cultural and legal aspects.

${ }^{1}$ Assistant Professor, DAV Centenary College, NH-3, Faridabad, Haryana

${ }^{2}$ Assistant Professor, DAV Centenary College, NH-3, Faridabad, Haryana

C 2015 I P jha, N Nagar; licensee IJIP. This is an Open Access Research distributed under the terms of the Creative Commons Attribution License (http://creativecommons.org/licenses/by/2.0), which permits unrestricted use, distribution, and reproduction in any Medium, provided the original work is properly cited. 
This problem is simply known as gender biasness, which in simple term means the gender stratification or making difference a male or a female. According to the United Nations Development Program's Human Development Report (2013), India ranks 132 out of 187 countries on the gender inequality index- lower than Pakistan (123). The report states that all countries in South Asia, with the exception of Afghanistan, were a better place for women than India, with Sri Lanka (75) topping them all.

Types of Gender Inequality: - According to Nobel Laureate Prof. Amartya Sen (2001), there are seven types of gender inequalities at present in India. Here is a brief explanation of all the types of gender inequality.

1) Mortality Inequality:- In this, Inequality between women and men directly involves matters of life and death, and takes the brutal form of unusually high mortality rates for women and a consequent preponderance of men in the total population, as opposed to the preponderance of women found in societies with little or no gender bias in health care and nutrition.

2) Natality Inequality: - In this kind of inequality a preference is given to boys over girls. It is ardent in many of the male dominated societies and these manifests in the form of parents wanting their newborn to be a boy rather than a girl. With the availability of modern techniques to determine the gender of foetus, sex selective abortions has become common in India.

3) Employment Inequality: - In terms of employment as well as promotion at work women often face greater handicap than men. This is clearly exemplified as men getting priorities in getting better work opportunities and pay scale than their female counterparts.

4) Ownership Inequality: - In many societies ownership of property can also be very unequal. Since ages the traditional property rights have favored men in the most parts of India. The absence of claims to property can not only reduce the voice of women, but also make it harder for women to enter and flourish in commercial, economic and even some social activities.

5) Special Opportunity Inequality: - Even when there is little difference in basic facilities including schooling, the opportunities of higher education may be far fewer for young women than young men. Indeed, gender biasness in higher education and professional training can be observed in India.

6) Basic-Facility Inequality: - Even when demographic characteristics do not show much or any anti-female bias, there are other ways in which women can have less than a square deal.

7) Household inequality: - There are often enough, basic inequalities in gender relations within the family or the household, which can take many different forms. Even in cases in which there are no overt signs of anti-female bias in, say, survival or son-preference or education, or even in promotion to higher executive positions, the family arrangements can be quite unequal in terms of sharing the burden of housework and child care. 


\section{HISTORY OF GENDER INEQUALITY}

If we highlight ancient India, an Indian woman was in the position of high esteem and was pronounced by the word of maata (mother) or Devi (goddess) in the Vedas and Upanishads. Same as Manu Smriti, woman was considered as a precious being and in the early Vedic age, girls were looked after with care. Then practice of polygamy deteriorated the position of woman and in the medieval period, the practices of purdha system, dowry system, and sati system came into being. But with the passage of time, the status of woman was lowered.

After the development of science and technology, female feticides is being practiced by large number of people. This has also led to a drop in the female ratio. The Indian census 2011 state wise shows that Kerala represent the highest sex ratio with 1084 females per 1000 males while Haryana represents the lowest sex ratio with just 877 women per 1000 males. Then the dowry became popular and it was the starting period of female infanticide practices in few areas.

In India, a sex-selection phenomenon has been in place since the 1980s, with men born during this period now at marriageable age. Then the urbanization since the 1990s where a lot of families and men have moved to cities to look for work. People are much wealthier but at the same time there's pressure to produce sons as an heir, so educated, wealthy families are now more likely to have sex selection. These entire factors are coming to play and creating this toxic mixture, which has turned violence against women into a bigger issue today.

The origin of the gender inequality has been always the male dominance. At least in India, a woman still needs the anchor of a husband and a family. Their dominating nature has led women to walk with their head down. It was all practiced from the beginning and is followed till date. In the case of a woman's reservation in parliament, the opposing parties believe that women are born to do household tasks and manage children and family.

In many parts of India, women are viewed as an economic and financial liability despite contribution in several was to our society, economy and by their families. The crime against women is increasing day by day. Domestic Violence, Rape, Sexual harassment, molestation, eveteasing, forced prostitution, sexual-exploitation, at work places are a common affair today. So, it's an alarming issue for our country.

The major reasons for the gender inequality are identified as the need of a male heir for the family, huge dowry, continuous physical and financial support to girl child, poverty, domestic violence, farming as major job for poor and the caste system. 


\section{A Study of Gender Inequality In India}

\section{REVIEW OF LITERATURE}

Jayachandran, S. (2014), has presented the roots of gender inequality in developing countries. This paper also discussed the several mechanisms through which the economic development could improve the relative outcomes of women $\&$ gender gaps can be reduced as country grows.

Dunn, D. (1998), has focused on the situation of women in scheduled castes and tribes groups which are considered to as 'weaker sections of people' and granted special safeguards and concessions under the Indian Constituents. This paper represented a descriptive picture of scheduled caste and tribe women's status in Indian society and also suggested that socioeconomic development plays an important role to reduce the disadvantage of scheduled group women.

Thomas, R.E. (2013), has highlighted his paper with the state of gender based inequality in the modern India. It has presented gender inequality with the help of some facts \& figures and representing the inequality practiced in India \& its comparison with other Asian \& Western countries.

Chaudhary, \& Sarkar, D. (2012), has tried to find out some factors i.e. educational status, work participation, level of gender inequality, of the Cooch Behar, a district of West-Bengal, India and suggested some relevant strategies implication for reducing this gender inequality to promote the deprived women of this district.

Raju, E. (2014), has examined the gender discrimination in India on the basis of demographic, social, economic and political context. The paper has broadly discussed the issue of gender inequality, women empowerment\& reproductive health among women of India. Some measures under taken $b$ the International and national organizations were also discussed in this paper.

Rustagi, P. (2005), has concluded the weal potential of economic growth \& increasing women's economic participation towards eliminating gender inequalities in income \& wages, unless supported b concerted efforts at altering attitudes towards women's role \& contribution that are harbored by different agents within the labor market.

\section{OBJECTIVES OF THE STUDY}

1) To identify the factors which are responsible for gender inequality.

2) To give suggestions to reduce gender inequality. 


\section{FACTORS BEHIND GROWING GENDER INEQUALITY}

There are so many factors which are fully responsible for gender inequality in India. These factors are as follows:-

\section{ECONOMIC FACTORS}

$>$ Labor participation: - There is wage inequality between man and woman in India. A substantial number of women enter the labor market after thirties, generally after completion of their reproductive roles of child bearing and rearing.

> Access to credit: - There are large disparities between men and women in terms of access to banking services. Women often lack collateral for bank loans due to low levels of property ownership and micro-credit schemes have come under scrutiny for coercive lending practices.

> Occupational inequality: - Women are not allowed to have combat roles in military services. Permanent commission could not be granted to female officers because they have neither been trained for command nor have been given the responsibility in India.

> Property Rights: - Although women have equal rights under the law to own property and receive equal inheritance rights, yet in practice, women are at a disadvantage. The Hindu Succession Act of 2005 provides equal inheritance rights to ancestral and jointly owned property, the law is weakly enforced.

$>$ Women's inequality in proper inheritance:-Women are insignificantly deprived of their proper inheritance culturally and religiously as well. The religious constitution doesn't give women equal inheritance; there is a segregation of giving the property to women as they will not be given the property as men can have. Though Islamic constitution permits women having at least half of the property as man, society is reluctant to give the desired property to women let alone giving the equal share.

$>$ Employment inequality: - Some common inequalities that take place in the workplace are the gender-based imbalances of individuals in power and command over the management of the organization. Women are not able to move up into higher paid positions quickly as compared to men. Some organizations have more inequality than others, and the extent to which it occurs can differ greatly. In the workplace the men usually hold the higher positions and the women often hold lower paid positions such as secretaries. 


\section{SOCIAL FACTORS}

D Education: - The female literacy rate in India is lower than the male literacy rate. According to census of India 2011, literacy rate of female is $65.46 \%$ compared to males which are $82.14 \%$.

> Health:- On health issue, the gender inequality between women's and men's life expectancy and women live compared to men in good health because of lots of violence, disease, or other relevant factors.

$>$ Patriarchal Society: - Most of India has strong patriarchal custom, where men hold authority over female family members and inherit property \& title. It is the custom where inheritance passes from father to son, women move in with the husband $\&$ his family upon marriage \& marriages include a bride price or dowry.

$>$ Dowry: - The dowry system in India contributes to gender inequalities by influencing the perception that girls are a burden on families. Such belief limits the resources invested by parents in their girls and limit her bargaining power within the family.

$>$ Gender-based violence: - Gender-based violence such as rape, sexual assault, insult to modesty, kidnapping, abduction, cruelty by intimate partner or relatives, importation or trafficking of girls, persecution for dowry, indecency and all other crimes are practiced on women. These crimes show the high degree of inequality in India.

$>$ Women's inequality in decision making: In India, Women have less authority than men to legal recognition and protection, as well as lower access to public knowledge and information, and less decision-making power both within and outside the home. This is also one of the reasons for inequality in gender.

\section{CULTURAL FACTORS}

Old age support from sons: - A key factor driving gender inequality is the preference for sons, as they are deemed more useful than girls. They are supposed to support the old age security of their parents.

> Patrilineality system: - It is a common kinship system in which an individual's family membership derives from and is traced through his or her father's lineage It generally involves the inheritance of property, names, or titles by persons related through one's male kin.

$>$ Role of sons in religious rituals: - Another factor is that of religious practices, which can only be performed by males for their parents' afterlife. Sons are often the only person entitled to performing funeral rights for their parents.

$>$ Son Preference: - Boys are given the exclusive rights to inherit the family name and properties and they are viewed as additional status for their family. Moreover, the prospect of parents 'losing' daughters to the husband's family and expensive dowry of daughters further discourages parents from having daughters. There is a strong belief that daughter is a liability. 


\section{LEGAL \& POLITICAL FACTORS}

According to the Constitution of India, both men and women are equal in the eyes of the laws and hence they have equal rights. But, unfortunately, legal \& political bias has prevented the law to attain the success of equality in gender. This is another reason for inequality in gender.

ANALYSIS \& INTERPRETATION: - From the above factors, we can interpret that economic, social, cultural, legal and political factors are responsible for gender inequality in India. India needs to deactivate the gender Inequality. The needs of the day are trends where girls are able not only to break out of the culturally determined patterns of employment but also to offer advice about career possibilities that looks beyond the traditional list of jobs. It is surprising that in spite of so many laws, women still continue to live under stress and strain. To ensure equality of status for our women we still have miles to go. Man and Woman are like two wheels of a carriage. The life of one without the other is incomplete.

SUGGESTIONS: - There is a solution of every problem. For reducing gender inequality in India, we should offer high level of education to girls and increase women empowerment. We should also give them opportunity in active politics \& social activities so that social integration in Indian society can be made. Government should make policies \& strategies regarding stopping the sex identification \& abortions. In context of above NGOs can also play an important role to eradicate Gender Inequality. Politicians should frame out policies for increasing social welfare development regarding this issue. The Campaign of our Prime Minister Mr. Narender Modi "Beti Bachao Beti Padhao" can be successful, when the mindset of Indian society will be changed towards women.

\section{REFERENCES:-}

1. Barro, Robert J., and Jong-Wha Lee (1994): Sources of Economic Growth, CarnegieRochester Conference on Public Policy, 40: 1-46.

2. Berta - Esteve - Volast, (2007), "Gender discrimination and Growth: Theory and Evidence from India," London, London School of Economics and Political Sciences.

3. Kabeer, N (1999) 'From Feminist Insights to an Analytical Framework: An Institutional Perspective on Gender Inequality'

4. Razavi, S (2003), 'Women's changing roles in the context of economic reform and globalization'. Background paper for EFA Global Monitoring Report 2003/04

5. Santosh Ranganath N., Kama Raju T. (2009), "Gender Development in India: Dimensions and Strategies", Management Trends, Vol. 6, No. 1 \& 2, ISSN: 0973-9203, pp. $120-126$

6. Seguino, Stephanie. (2006). "Gender Equality and Economic Growth: A Cross-Country Analysis", World Development, Vol. 28, No. 7, pp. 67-71.

7. Singh, Ajit and Ann Zammit. (2007), "International Capital Flows: Identifying the Gender Dimension", World Development, Vol. 29, No. 7, pp 1249-1268. 
8. Sunden, Annika and B. Surette. (2008), "Gender Differences in the Allocation of Assets in Retirement Savings\Plans", American Economic Review, Vol. 88, No. 2, pp. 207-211.

9. UNESCO, Gender and Education for All: The Leap to Equality- Summary Report (2003) (hereinafter referred to as UNESCO Summary Report) at p1, available at http://www.efareport.unesco.org/ UNICEF Basic information and gender equality: http://www .unicef.org/girlseducation/index_statistics.html

10. Velkoff, Victoria A. (1998). Women "s Education in India. Report by the U.S. Dept. of Commerce, Washington: GPO, http://www.census.gov/ipc/prod/wid-9801.pdf

11. Wilson, D (2003) Human Rights: Promoting gender equality in and through education. Background paper for EFA GMR 2003/4 